\title{
SHORTWAVE RADIO AND THE FOREIGN LANGUAGE CLASSROOM
}

\author{
Philip D. Smith
}

West Chester State College, Pennsylvania

\section{Introduction}

The use of radio in second language teaching has by now a long honorable, and still meagre tradition. Despite an ERIC report (Nelson, 1969), a few excellent articles, (Graphical, 1972, (Therrien, 1973, Mohr and Lally, 1973), and sometimes good results, (Connor, 1976) radio is simply not used as widely as it could be. Recent interest may indicate increasing use of radio despite some of the very realistic obstacles that face the beginner.

Radio can be used imaginatively in a variety of ways. These include ( 1 ) increasing the reality, currency, and accuracy of listening and listening comprehension skills; (2) actual communication with speakers of the target language and cultural; (3) stimulating real interstudent communication in the target language. Let us examine the use of each of these areas in order - and also examine frankly the problems presented by each.

1. The world of radio, both Broadcast $(B C)$ and Shortwave (SW) brings the real world into the language classroom. It is a strange but true phonomenon that students will place far greater confidence in a voice from a box rather than in a printed page. For American teenagers, $\mathrm{Oz}$ is a real place, much more real-and, indeed, better known-than France or Germany.

Most of America lies within range of daily live radio broadcasts in French and Spanish on the standard AM radio. German is available in many metropolitan areas. In the Philadelphia area the spectrum ranges from the "Lithuanian Hour" to the "Irish Hour."

Shortwave broadcasts roll in from around the world and go out, via the Voice of America, on a twenty-four hour a day basis. The language is clear, well-articulated, and at a slower-than-conversational speech. Particularly in news broadcasts and advertisements, large numbers of proper names, cognates, and loan words abound. Broadcasts are current, topical, and intended for easy understanding.

There is literally more material than the average teacher can usebut using some of it is well forth the effort, especially for students in Levels III and above.

First it must be captured-tuned, the volume set, recorded, listened to, and perhaps must be written and packaged. Are students to repeat?, then it must be "exploded." Are they to paraphrase? Answer questions? Discuss? Report? Criticize? All of these bring real language and ideas into real focus; all require teacher preparation and materials. 
Most Foreign Language teaching is unsuccessful in the long run because it is unreal psychologically to students. We teach language but we never really have anything important to talk about. Radio can help complete the psychological reality of the target language. Problems? Certainly. The biggest is time. Shortwave listening requires patience. Where is Radio Brazzaville? What time? Buy and learn to use a good receiver. Expect to pay a lot-once. A good receiver should last twenty years or more.

Spend time listening. Radio listening requires good language skills on the part of the teacher. Radio broadcasts are often noisy and distorted. A dedicated listener often can hear a station where the visitor only hears noise. Noise is not what foreign language teachers want. Our students need good, fairly clear reception, but it will take patience and practice to be able to find classroom quality broadcast with some regularity.

Recording should be by direct wire connection from radio to tape recorder, but also audible to the operator. Before recording, the radio should be turned on for $\mathbf{3 0}$ minutes to avoid "drifting" away from a desired station.

After students have become familiar with the process, tapes can be placed in the laboratory or learning center or issued to students along with accompanying worksheets; it is better never to do in classtime than which can be done in addition to classtime. Except as a motivational device, random student listening is not profitable.

2. Amateur Radio is a motivational medium which has seldom been uscd by foreign language teachers. There are more than 250,000 "hams" in the United States, probably half of them equipped and licensed for intercontinental two-way voice communications. Daily contacts with Europe or South America are routine.

Planned demonstrations have a way of being demonstrations of Murphy's Law of Electronics-"That which can go wrong, will." Temporary or portable stations usually do not perform as well as home stations so classes are better off to visit a ham unless he or she can come to school for several hours. With a phone patch, incoming transmissions can be brought into the classroom over the intercom system.

Amateurs with established routine contacts with friends who speak the target language can arrange a scheduled contact in which students can participate. Questions can be written out, students selected to speak and alternative plans made. Radio amateurs in some countries are restricted in the topics they may discuss or may be prohibited from talking to persons other than the American amateur. The local radio amateur will be aware of nations which prohibit "third party traffic" (it competes with the 
money-earning telephone systems, often a government monopoly). Careful pre-planning of topics will provide many good language activities. Where does the person live? What is his family like? What are his other interests? Favorite foods? Not all "hams" are in the electronics field; the author has talked with priests, florists, teachers, and students-and learned about German law enforcement from an off-duty Bremen policeman.

Be prepared with an alternate activity, however. You never know when the electricity will go off in a suburb of Lyons or when the telephone will ring in Bogota.

3. Real communication via low-powered radio can be a big motivator (see Garfinkel, 1969). Many a quiet student has become a chatterbox when connected to a live telephone. The current CB fad may well do the same, providing a media and stimulation for the exchange of information between two points in the school.

With only the foreign language permitted, some students would be delighted to find and use the target language equivalent of "ham" or "CB" jargon. The old unit on Producing a Radio Show comes alive when the radio really works and talks back to you. Normally reticent adults undergo a noticeable personality changeMr. Milktoast becomes "Rampant Lion" and Mrs. Smertz next door is the super seductive "Red Hot Mama." Think what kids can do.

- Hola, "Flecha de Plata." ?Me oyes?

- ?Quien es?

— Soy "el Gaitero" y . . . etc, etc.

- Pues, setenta y tres. Cambio.

- Hasta luego amigo, setenta y tres.

Radio transmissions must be in real languages (Esperanto permitted) and are not limited to English. Transmissions via CB over any great distance is prohibited by law. Amateur radio is the way to go for international communication but many of our classrooms are within a mile or two of a native speaker. Just be sure they are briefed on the topic and language level of your students.

\section{Transmission and Reception}

Problems in speech transmission and reception make language comprehension of radio broadcasts one of the real differentiators between skilled and unskilled listeners. During a recent workshop to develop new competency statements for Pennsylvania Foreign Language teachers, Tom Bruni of Allentown, only half in jest, suggested, "Let's call them on the phone. If they can understand the second language then they're competent." (See also Smith, 1967) 
The bandwidth of radio transmissions is often reduced artificially at transmission to permit concentration of transmitting power. Voice transmission usually requires broadcast of frequencies to $10,000 \mathrm{~Hz}$ (cycles per second). Because of the redundancies known to native speakers, voice communications by radio and telephone are often restricted to $4000 \mathrm{~Hz}$. Radio amateurs and other point-to-point communicators only need 2500 $\mathrm{Hz}$.

For the non-native speaker (read language learner) this presents some real problems:

"As a result of experimentation we find that the ability of beginning students to distinguish and repeat syllables decreases markedly in German and perceptibly in French as the frequency response of equipment is progressively reduced from 7300 cycles per second, to 5000 and 3000 . (Buka, Freeman and Locke, 1962"). The difficulty is caused by the removal of information required to transmit certain consonant phonomena, typically $\mathrm{N}, \mathrm{f}, \mathrm{O}, \mathrm{z}, \mathrm{s} /$.

Add to this the lack of a visual context and the fading and noise often inherent in radio transmission. Listening to a shortwave broadcast can be somewhat difficult even in a familiar language; it really does "separate the boys from the men" in a foreign language.

Yet, it may be doing our students a favor to force them to strain a little as they listen. Without strain there is no work being done. A few years ago one of the unpublicized results of the Pennsylvania Foreign Language Research Project (Smith, 1970) indicated that on French and German listening tests, students who used the Holt texts did significantly better than those who used the A-LM. Perhaps this was due to the Holt listening tapes that purposefully recombined materials and introduced sound effects ad background noise.

The voices of the real world are out there, in truth they are everywhere, all around each of us in minute electrical vibrations. The radio receiver is a window. Open it up and let those real voices of real people reach through and touch the minds of your students.

\section{Obtaining an Amateur License}

To obtain a radio amateur license to operate radio telephone on the longdistance bands, the applicant must appear before the examiner of the Federal Communications Commission at one of a number of examining centers and do three things: (1) pay an application fee; (2) successfully send and receive plain English text in the International Morse Code at a speed of thirteen words per minute; and (3) pass a written test on radio theory and regulations. Let us look at each of these in turn. The fee is the easiest part, but remember that it is not refundable. You don't get your money back if you fail either the code or theory test. You forfeit the fee 
as your price for trying. The beginner may take the test for the "Novice" class license from an Advanced or Extra Class Amateur without having to appear before the FCC.

The code test seems a questionable and difficult hurdle for many aspiring radio operators. Neither is true. A code test for a long distance transmitting license is required by international law for amateurs in all nations. It has a very and practical application even in this sophisticated age. First, code is used in "dire" emergency situations; it goes farther per watt, is easier to understand through static, and can be produced by a simple "jury-rigged" radio or a light. Secondly, it allows emergency communication with amateurs who cannot speak each other's language.

Learning the code is admittedly difficult for some, time-consuming for everyone. Fortunately, the "Novice" Class License permits a beginner to begin at a relatively low technical level and code speed. Speed and skill increase while actually "on the air."

Class

Novice

Technician

General

Advanced

Extra

\section{Requirements}

code $5 \mathrm{wpm}$, simple theory code $5 \mathrm{wpm}$, general theory code $13 w p m$, general theory code $13 \mathrm{wpm}$, advanced theory code $20 \mathrm{wpm}$, advanced theory

\section{Privileges}

code operation, SW bands code \& voice, VHF bands code \& voice, limited SW code \& voice, many SW extra code frequencies

The Novice examination has recently been passed by a 5-year old.

A typical "ham" station consisting of a SW Transmitter/receiver in the 200-300 watt class with a modest antenna is fully capable of world-wide communication, depending upon the patience, skill, and times of operation.

For information or help, contact the American Radio Relay League, 225 West Main Street, Newington, Connecticut, for the name of a "ham" club in your area. Classes are offered by clubs, schools, and individuals throughout the year.

Check local Boy Scout Headquarters for the names of Radio Merit Badge Counselors. They will almost always be "hams" dedicated to helping interested beginners to obtain a license.

"Hams" will also help you get on the air, often by helping beginners to locate and set up less expensive equipment. You may even be allowed to operate their stations until yours get established.

\section{BUYING A SHORTWAVE RECEIVER}

GOOD

1. STABILITY

2. SELECTIVITY

3. BANDSPREAD

4. SENSITIVITY
BAD

1. TOO MANY BANDS

2. CROWDED DIAL

3. LITTLE KNOBS

4. LITTLE CASE

5. BUILT-IN ANTENNA 


\section{SENSIBLES}
1. BANDS $6-18 \mathrm{M} \mathrm{Hz}$
5. EXTERNAL ANTENNA
2. AM / SSB ONLY
6. EARPHONE JACK
3. LARGE SPEAKER
7. LARGE KNOBS
4. RF AMPLIFIER
8. LONG (INCHES) DIAL - divisions 1 to $10 \mathrm{~K} \mathrm{~Hz}$

\section{A GOOD RECEIVER COSTS A LOT BUT LASTS A LIFE-TIME}

\section{BIBLIOGRAPHY}

Buka, M. M. Z. Freeman, and W. N. Locke. "Language Learning and Frequency Response." International Journal of American Linguistics 28,i(1962):62-79.

Connor, Maurice W. "From Short Story to Radio Play: An Inter-genre Experiment Using the Tape Recorder." NALLD Journal. 10,i(1976) :19-22.

Garfinkel, Alan. "The Effects of an Enrichment-oriented Radio Program on Measures of Listening Comprehension and Student Attitude Made in Level II High School Spanish Courses." Unpublished Ph.d. Dissertation, Ohio State University, 1969.

Garfinkel, Alan. "Teaching Languages via Radio: A Review of the Resources." Modern Language Journal 56,iii(1972):158-62.

Mohr, William, and Dale Lally. "Teaching German via Short-Wave Bröadcasts." Modern Language Journal 57,iii(1973):119-24.

Nelson, Robert J. Using Radio to Develop and Maintain Competence in a Foreign Language. ERIC Focus Report 11. New York: MLA Materials Center, 1969.

Smith, Philip D. "Teaching a Modern Language via Telephone." Unpublished Ph.d Dissertation., Ohio State University, 1967.

Smith, Philip D. A Comparison of the Cognitive and Audiolingual Approaches to Foreign Language Instruction: The Pennsylvania Foreign Language Project. Phi ladelphia, Pa.: Center for Curriculum Development, 1970.

Therrien, Melvin G. "Learning French via Short-Wave Radio and Popular Periodicals." French Review 46(1973):178-83. 